\title{
Case Study of Reducing the Occlusion Effect and Improving Telephone Usage and Cosmetic Satisfaction by Invisible-in-the Canal Hearing Aids
}

\author{
Kwang Jae Kim¹,2, Kyung Won Lee ${ }^{1}$, Junghwa Bahng ${ }^{1}$ \\ ${ }^{1}$ Department of Audiology, Hallym University of Graduate Studies, Seoul, Korea \\ ${ }^{2}$ Hearing Hub Center, Seoul, Korea
}

\author{
초고막형 보청기를 통한 폐쇄효과의 감소와 전화 사용 및 미용상의 만족도 향상 사례 \\ 김광재 ${ }^{1,2} \cdot$ 이경원 ${ }^{1} \cdot$ 방정화 $^{1}$ \\ 한림국제대학원대학교 청각학과', 히어링 허브 센터 ${ }^{2}$
}

\begin{abstract}
Purpose: One of the main complaints in hearing aid users is the abnormal perception of their voices, which is known as occlusion effect. Open fit hearing aids, for example, receiver-in-the-canal (RIC) hearing aid type is a good solution to the occlusion effect. However, here, two subjects avoid using RIC due to cosmetic unsatisfaction and difficulty of using a cell phone. The purpose of this study was to investigate the possibility of reducing the occlusion effect and improving cell phone usage and cosmetic satisfaction using invisible-inthe-canal (IIC) hearing aids. Methods: Two hearing impaired listeners who used bilateral RIC type hearing aids participated. IIC hearings were manufactured. Functional gain, real ear insertion gains, word recognition scores and a subjective hearing aids benefit questionnaire were assessed with RIC and IIC hearing aids, respectively. Subjective occlusion effect was also measured. Results: There were no differences in functional and insertion gains between two types of hearing aids. Participants did not complain the occlusion effect with IIC hearing aids. Conclusion: Although RIC hearing aids have an advantage of reducing the occlusion effects in both participants, they preferred to wear IIC hearing aids due to comforting of using a cell phone and cosmetic reasons. Results of the current study showed objective and subjective functions of RIC and IIC hearing aids were not different each other in both participants. The RIC hearing aid type, open-fit hearing aid, is not the only one option for reducing the occlusion effects; audiologists should consider the individual's needs.
\end{abstract}

Key Words: Occlusion effect, RIC hearing aid, IIC hearing aid, Telephone use, Cosmetic satisfaction.

Received: June 29, 2017 / Revised: July 10, 2017 / Accepted: July 10, 2017

Correspondence: Junghwa Bahng, Department of Audiology, Hallym University of Graduate Studies, 427 Yeoksam-ro, Gangnam-gu, Seoul 06197, Korea Tel: +82-70-8680-6933 / Fax: +82-2-3453-6618 / E-mail: bahng.jh@gmail.com

\section{INTRODUCTION}

난청인이 보청기를 착용했을 때 자신의 목소리가 울려서 들 리는 폐쇄효과(occlusion effect)는 주로 저주파수에서 경도 전 후의 청력역치레벨을 가진 난청인이 어려움을 호소한다(Carle et al., 2002; Dillon, 2012; Kiessling et al., 2005). 폐쇄효과의 발생원인은 성대의 울림이 하악 및 두개골(skull)을 통하여 외이 도 내에서 재생성되고 이 음압이 난청인이 착용한 보청기로 인 해 외이도 밖으로 배출되지 못하고 고막으로 전달되어 발생한
다. 폐쇄효과의 발생은 주로 고주파수보다는 낮은 저주파수 대 역의 어음을 발성할 때 발생하는데, 연구에 따르면 발성 시 입술 또는 치아가 닫히며, 제1포먼트가 $300 \mathrm{~Hz}$ 내외인 /이/, /우/ 등의 어음에서 주로 발생한다(Dillon, 2012; Lee \& Lee, 2013).

폐쇄효과는 저주파수의 이득을 조절하는 전기음향적 방법 과 귀꽂이(earmold) 또는 보청기외형(hearing aid shell)을 변형 하는 물리적인 방법을 통하여 어느 정도 해결할 수 있다. 폐쇄 효과를 해결하기 위한 전기음향학적 해결은 저주파수 대역의 이득 및 압축역치, 압축비율 등을 조절할 수 있지만(Lee \& Lee, 
2013), 저주파수의 이득이 너무 낮은 경우 어음인지에 필요한 정 보를 듣지 못할 수도 있다.

물리적인 방법을 통하여 폐쇄효과를 해결하는 방법은 크게 두 가지 방법으로 나눌 수 있다. 첫째, 외이도 안에서 재생성된 에너지가 밖으로 용이하게 배출할 수 있는 개방형 보청기를 사 용하는 방법이다. Fretz et al.(2001)에 따르면 개방적합보청기 는 귀꽂이 또는 보청기외형이 사용자의 외이도를 완전히 막지 않은 형태로 보청기 외부의 소리가 직접 고막으로 들어갈 수 있는 공간이 있는 보청기를 의미한다. 개방적합보청기는 수화기 가 외이도 내에 위치하여 receiver-in-the-canal (RIC)로 불리 는 귀걸이형이 있으며, 직경이 큰 ipsilateral routing of signal 형의 환기구를 설치한 귓속형이 있다. 이 두 가지 형태의 개방 적합보청기는 큰 직경의 환기구로 인해 발생할 수 있는 음향피 드백(acoustic feedback)을 효과적으로 제어할 수 있는 기술이 발전함에 따라 폐쇄효과를 효과적으로 해결할 수 있으며 음질, 방향성 등에 있어서도 효과가 있다(Mueller, 2006; Taylor, 2006). 재생성된 음압을 배출하는 방법에서 배출되는 음향의 양은 환기구의 길이 및 직경에 의해 결정된다. 즉, 환기구의 길 이가 짧을수록 그리고 직경이 클수록 배출되는 음향의 양이 많 아지며 이로 인해 폐쇄효과는 줄어들게 된다(Dillon, 2012; Kiessling et al., 2005; Lee et al., 2005). Kuk \& Keenan(2006) 의 연구에 따르면 환기구의 직경이 $1 \mathrm{~mm}$ 증가하면 약 $4 \mathrm{~dB}$ 의 음량이 줄어들어 객관적으로 폐쇄효과가 줄어든다고 보고하였 으며, 환기구의 길이에 따라 다르지만, 약 $5 \mathrm{~mm}$ 의 직경일 경우 폐쇄효과가 완전히 사라졌다. Kiessling et al.(2005)은 보청기 사용자 10명과 보청기 무경험자 9명을 대상으로 돔으로 연결된 RIC형에서 RIC, $3 \mathrm{~mm}$ 환기구를 가진 고막형(completely-inthe-canal, CIC) 보청기, 그리고 $1.6 \mathrm{~mm}$ 와 $2.4 \mathrm{~mm}$ 환기구를 가 진 귀꽃이와 연결된 귀걸이형(behind-the-ear, BTE) 보청기를 사용한 상태에서의 폐쇄효과를 비교하였다. 실험 결과에 따르 면 돔은 보청기 혹은 귀꽃이를 사용하였을 때보다 주관적 및 객관적으로 모두 유의하게 폐쇄효과가 줄어들었다고 보고하였 다. 또한 실험 참여자들은 돔을 사용했을 때 소리도 다른 보청 기보다 자연스럽게 들리고 보청기의 착용감도 편안하다고 보고 하였다.

둘째, 보청기외형을 깊게 그리고 꽉 차게(tight fit) 삽입하는 방법이다. 말을 할 때에는 주로 외이도의 연골부위의 움직임으 로 인하여 에너지가 외이도 안에서 생성될 수 있는데 보청기의 외형이 외이도에 꽉 차게 제시될 때 재생성되는 음압을 줄이는 방법이 있다(Winkler et al., 2016). 외이도의 표면에 닿는 보청 기 접촉면과 보청기 폐쇄효과 관련 실험에서 면적이 넓을수록 폐쇄효과의 해결에 효과적이다(Lee \& Lee, 2013; Lee \& Park, 2016; Lee et al., 2005). Pirzanski(1998)의 실험 결과 고막형
(CIC) 보청기의 외형을 만들 때 최대한 꽉 차게 제작하였을 때 환기구가 없어도 폐쇄효과가 나타나지 않았다.

Mueller(2006)의 연구에 의하면 미국의 경우 보청기 사용자의 $40 \%$ 이상이 개방적합보청기를 착용하고 있으며, 우리나라의 경 우에도 계속적인 증가 추세를 보이고 있다. 개방적합보청기는 앞에서 언급한 폐쇄효과를 감소시키는 점에 있어서 효과적이 라고 할 수 있으나 실이측정에 어려움을 줄 수 있으며, 직접 고 막에 전달된 음과 증폭음의 상호작용에 의한 음질의 저하 그리 고 방향송화기와 잡음제어 기능에 좋지 않은 영향을 줄 수 있 는 한계점이 있다(Winkler et al., 2016). 또한 앞으로 언급하게 될 사례에서 보듯이 우리나라에서는 외관으로 보이는 보청기 에 대한 거부감이 있을 수 있으며, 전화기사용 시 마이크로폰 의 위치로 인하여 전화기를 받기가 용이하지 않다는 단점이 있 다. 전화기받기의 경우 스마트폰의 보급으로 블루투스(bluetooth)의 기능을 사용하여 RIC형 보청기를 사용하더라도 용이 하게 전화기를 사용할 수 있으나 아직 많이 보편화되지 않았으 며 일부 모델에 한정적으로 적용하고 있다.

본 연구에서는 폐쇄효과로 인하여 RIC형 보청기를 사용하 고 있던 난청인이 전화기 사용의 불편함과 외관상 노출에 대한 불만족을 호소한 사례로, 초고막(invisible-in-the-canal, IIC) 형 보청기로 교체하여 폐쇄효과와 아울러 전화사용 및 미용상 의 만족도를 동시에 향상시킨 내용을 보고하고자 하였다.

\section{MATERIALS AND METHODS}

\section{연구 대상}

연구에 참여한 두 대상자는 본인의 검사결과 등을 연구에 사용해도 좋다는 동의서를 작성하였다. 대상자 1 은 60 세 여성 으로 2016년 8월 5일부터 2016년 11월 8일까지 히이링허브센터 를 방문하였다. 대상자는 5년 전 이비인후과에서 난청을 발견 하여 고막보청기를 사용하였으나 본인의 목소리가 심하게 울려 서 RIC형 보청기로 교체하여 사용하였다. RIC형 보청기로 교 체한 이후 폐쇄효과는 해결되었지만 전화기의 사용이 불편하 여 IIC형 보청기의 착용을 시도하기 위하여 방문하였다.

대상자 2는 26세의 남성으로 출생 직후 경도난청으로 진단 받았으나 보청기는 착용하지 않았다. 약 5년 전에 중도난청으 로 판정을 받아 폐쇄효과가 덜한 양쪽 RIC형 보청기를 착용하 였다. 그러나 외형적으로 더 눈에 띄지 않는 보청기로 교체를 원하여 본 센터에 방문하였다. 현재 생산 현장 관리자로 소음에 노출된 환경에서 근무하고 있으며, 평소 음악듣기를 좋아한다 고 보고하였다. 특별한 건강의 이상은 없으며 부친의 청력이 고 도의 감각신경성난청이었다. 대상자 1,2 에 대한 기도 및 골도 청력역치레벨은 다음과 같다(Table 1). 
Table 1. AC and BC hearing threshold levels ( $\mathrm{dB} H \mathrm{HL})$ of subjects

\begin{tabular}{|c|c|c|c|c|c|c|c|}
\hline & \multicolumn{6}{|c|}{ Frequency in $\mathrm{Hz}$} & \multirow{2}{*}{$\begin{array}{c}\text { WRS } \\
(\%)\end{array}$} \\
\hline & 250 & 500 & 1,000 & 2,000 & 4,000 & 8,000 & \\
\hline \multicolumn{8}{|c|}{ Subject 1} \\
\hline \multicolumn{8}{|l|}{$\mathrm{AC}$} \\
\hline Rt & 15 & 15 & 35 & 60 & 65 & 70 & 64 \\
\hline $\mathrm{Lt}$ & 15 & 15 & 55 & 65 & 70 & 85 & 60 \\
\hline \multicolumn{8}{|l|}{$\mathrm{BC}$} \\
\hline Rt & & 15 & 35 & 60 & 65 & & \\
\hline Lt & & 15 & 55 & 60 & 65 & & \\
\hline \multicolumn{8}{|c|}{ Subject 2} \\
\hline \multicolumn{8}{|l|}{$\mathrm{AC}$} \\
\hline Rt & 30 & 55 & 65 & 65 & 70 & 85 & 56 \\
\hline $\mathrm{Lt}$ & 30 & 55 & 80 & 85 & 90 & 80 & 52 \\
\hline \multicolumn{8}{|l|}{$\mathrm{BC}$} \\
\hline Rt & & 50 & 65 & 65 & 70 & & \\
\hline $\mathrm{Lt}$ & & 50 & 70 & CNT & CNT & & \\
\hline
\end{tabular}

AC: air conduction, $\mathrm{BC}$ : bone conduction, WRS: word recognition score, CNT: cannot test

\section{연구 방법}

\section{연구 장비}

대상자의 보청기 착용 전 기도 및 골도 청력역치레벨 및 단어 인지도의 평가는 방음실에서 청력검사기기 AD629B (Interacoustics, Copenhagen, Denmark)와 TDH-49 헤드폰(Interacoustics)을 착용하여 실시하였다. 보청기의 성능분석과 실이측 정은 Affinity 2.0 (Interacoustics)으로 실시하였으며, 방음실에 서 보청기 착용 전후의 단어인지도 평가는 한국표준(Korean Agency for Technology and Standards, 2009) 어음청각검사 (Korean Speech Audiometry)의 Korean standard-monosyllabic word level-adult의 단음절 목록을 사용하였다. 그리고 RIC 형 및 IIC형 보청기 착용 시 실생활에서의 주관적 이득 평가는 Korean profile of hearing aid benefit (K-PHAB) (Kim et al., 2016), 주관적인 폐쇄효과는 대상자의 주관적인 보고 사항을 평가하였다.

\section{$\| C$ 형 보청기의 제작}

상담을 통하여 연구 대상자가 새롭게 착용한 보청기는 IIC형 보청기로 고막에 최대한 가까이 채취한 귓본(ear impression)을 이용하였다. 보청기는 최대한 고막 가까이 삽입될 수 있으며, 폐 쇄효과를 최대한 방지하기 위하여 보청기, 특히 골부(bony part)의 표면이 최대한 외이도 표면에 닿을 수 있도록 제작하였 다. 환기구의 직경은 대상자 1 과 2 가 각각 $0.5 \mathrm{~mm}$ 와 $0.8 \mathrm{~mm}$ 였다.
Table 2. Functional gain (dB) of RIC and IIC type of hearing aid in subjects

\begin{tabular}{cccccc}
\hline & \multicolumn{5}{c}{ Frequency in $\mathrm{Hz}$} \\
\cline { 2 - 5 } & 250 & 500 & 1,000 & 2,000 & 4,000 \\
\hline Subject 1 & & & & & \\
RIC & & & & 30 & 15 \\
Rt & -5 & 0 & 15 & 30 & 20 \\
Lt & -5 & -5 & 15 & & \\
IIC & & & & 30 & 25 \\
Rt & 5 & 5 & 20 & 35 & 35 \\
Lt & 5 & 10 & 20 & & \\
Subject 2 & & & & & \\
RIC & & & & 25 & 10 \\
Rt & 5 & 5 & 20 & 25 & 30 \\
Lt & 5 & 10 & 15 & & \\
IIC & & & & 35 & 20 \\
Rt & 10 & 20 & 35 & 30 \\
Lt & 15 & 30 & 30 & 35 & 35 \\
\hline RIC: receiveryyyyy
\end{tabular}

RIC: receiver-in-the-canal, IIC: invisible-in-the-canal

\section{연구 절차}

두 가지 유형의 착용효과를 비교하기 위하여 RIC형 보청기는 기존 착용하고 있던 상태 그리고 IIC형 보청기는 보청기 착용 후 2 주 동안 2 회의 조절을 마친 후 전기음향적 특성의 분석과 실이측정을 실시하였다. 방음실에서의 단어인지도는 대상자 모 두 RIC형 보청기는 IIC형 보청기를 착용하기 전의 방문 당일에, $\mathrm{IIC}$ 형 보청기는 2 회의 보청기 조절이 끝난 후에 측정하였다. 단 어인지도 검사는 피검자의 정면 $1 \mathrm{~m}$ 의 거리에 스피커를 위치하 고 $50 \mathrm{~dB} \mathrm{HL}$ 의 단음절을 제시하고 측정하였다. 그리고 $\mathrm{K}-$ $\mathrm{PHAB}$ 의 1차 설문은 IIC형 보청기의 착용 전 그리고 2차 설문 은 IIC형 보청기를 착용하고 2차 조절을 마친 2주 후에 실시하 였다.

\section{RESULTS}

\section{기능이득}

보청기를 착용하고 2 주간 2 회의 보청기 조절을 실시한 후 방 음실에서의 보청기 착용 전후 청력역치레벨의 차이인 기능이득 (functional gain)을 통하여 보청기적합을 확인하였다. Table 2 에서 기능이득의 차이는 대상자 1과 2 모두 약 $5 \sim 10 \mathrm{~dB}$ 정도 로 나타나 RIC형와 IIC형 보청기 간의 이득은 차이가 크지 않 음을 확인하였다.

\section{실이삽입이득}

보청기의 기능을 확인하기 위하여 실이측정을 실시하였다. 실이측정 시 실이삽입이득(real-ear insertion gain, REIG)의 
Table 3. Real-ear insertion gain (dB) of RIC and IIC type of hearing aid in subjects

\begin{tabular}{cccccc}
\hline & \multicolumn{5}{c}{ Frequency in $\mathrm{Hz}$} \\
\cline { 2 - 6 } & 250 & 500 & 1,000 & 2,000 & 4,000 \\
\hline Subject 1 & & & & & \\
RIC & & & & & \\
Rt & 2 & -4 & 7 & 18 & 10 \\
Lt & 7 & -8 & 8 & 10 & 12 \\
IIC & & & & & \\
Rt & 7 & 4 & 16 & 12 & 10 \\
Lt & 2 & -8 & 8 & 10 & 12 \\
Subject 2 & & & & & \\
RIC & & & & & \\
Rt & 14 & 9 & 17 & 28 & 15 \\
Lt & 5 & 7 & 23 & 43 & 22 \\
IIC & & & & & \\
Rt & 8 & 9 & 27 & 38 & 22 \\
Lt & 10 & 20 & 37 & 42 & 25 \\
\hline
\end{tabular}

RIC: receiver-in-the-canal, IIC: invisible-in-the-canal

Table 4. Word recognition scores (\%) wearing RIC and IIC type of hearing aid

\begin{tabular}{lccc}
\hline & \multicolumn{3}{c}{ Type of hearing aid } \\
\cline { 2 - 4 } & Unaided & Aided (RIC type) & Aided (IIC type) \\
\hline Subject 1 & & & 72 \\
Rt & 36 & 72 & 72 \\
Lt & 32 & 76 & 76 \\
Subject 2 & & & 68 \\
Rt & 44 & 72 & \\
Lt & 28 & 68 &
\end{tabular}

RIC: receiver-in-the-canal, IIC: invisible-in-the-canal

결과는 Table 3에 제시하였다. 대상자 1의 경우 RIC형과 IIC형 보청기의 REIG는 많은 차이가 나타나지 않았으나, 대상자 2의 경우 IIC형 보청기의 REIG는 오른쪽이 고주파수 영역에서 약 $10 \mathrm{~dB}, 1,000 \mathrm{~Hz}$ 에서 약 $14 \mathrm{~dB}$ 정도 높게 나타났다.

\section{단어인지도}

Table 4는 대상자 1과 2에 대하여 RIC형과 IIC형 보청기의 착용 후 단어인지도를 비교한 결과이다. 검사는 방음실에서 보 통 크기의 대화음 레벨인 $50 \mathrm{~dB} \mathrm{HL}$ 로 단음절어를 제시하여 보청기 착용 전 그리고 RIC형 및 IIC형 보청기를 착용하고 실 시하였다. 대상자 1 과 2 모두 두 보청기에서의 단어인지도는 큰 차이가 나타나지 않았다.

\section{$\mathrm{K}-\mathrm{PHAB}$}

보청기 적합 후 주관적인 보청기이득평가는 Kim et al.(2016) 이 개발한 $\mathrm{K}-\mathrm{PHAB}$ 를 사용하였다. 보청기이득평가는 RIC형과 $\mathrm{IIC}$ 형 보청기 착용 시의 $\mathrm{K}-\mathrm{PHAB}$ 점수를 비교하였다(Figure 1,

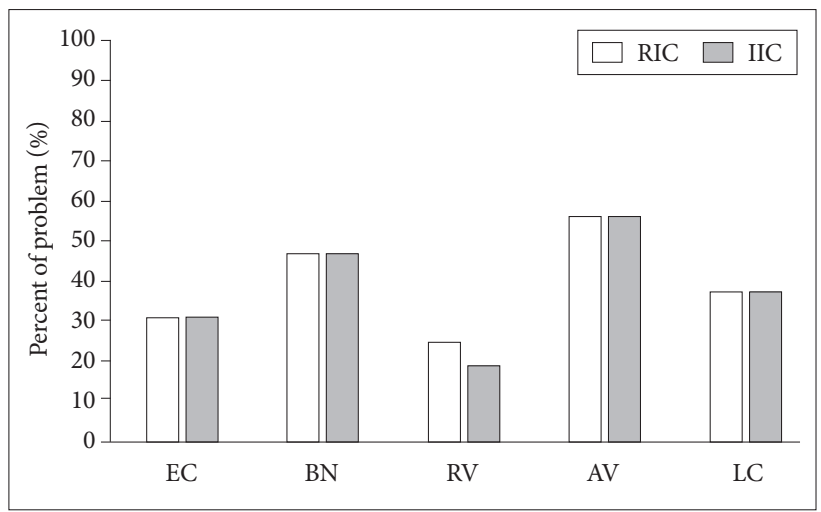

Figure 1. K-PHAB scores of subject 1. K-PHAB: Korean profile of hearing aid benefit, EC: easy of communication, BN: background noise, RV: reverberation, AV: aversiveness, LC: localization, RIC: receiver-in-the-canal, IIC: invisible-in-the-canal.

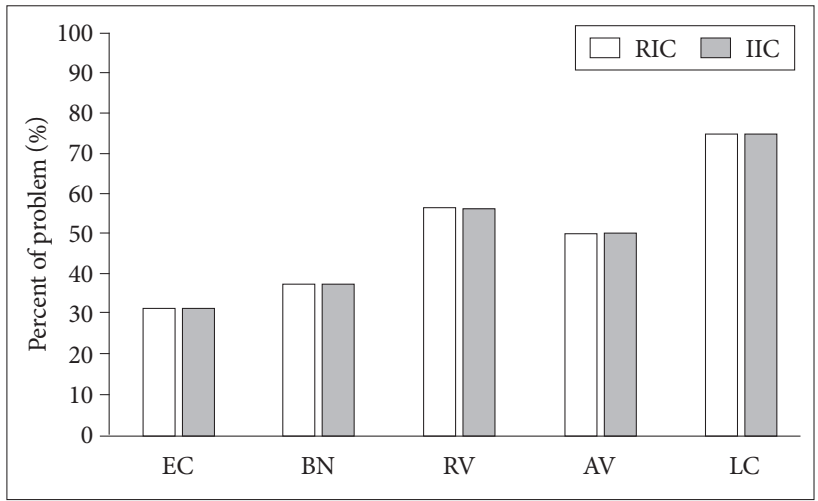

Figure 2. K-PHAB scores of subject 2. K-PHAB: Korean profile of hearing aid benefit, EC: easy of communication, BN: background noise, RV: reverberation, AV: aversiveness, LC: localization, RIC: receiver-in-the-canal, IIC: invisible-in-the-canal.

2). 대상자 1 과 2 모두 RIC형과 $\mathrm{IIC}$ 형 보청기 착용 시 $\mathrm{K}-\mathrm{PHAB}$ 의 점수에는 큰 차이가 없는 것으로 나타났다.

\section{폐쇄효과의 주관적 평가}

두 대상자 모두 RIC형 보청기를 폐쇄효과를 해결하기 위해 착용하였을 때 자신의 목소리가 울리지는 않는다고 보고하였 다. 또한 IIC형 보청기를 착용했을 때에도 두 대상자 모두 일상 생활에서의 대화 시에 본인의 목소리가 울리지 않고 자연스럽 다고 보고하였다.

\section{기타 주관적 평가}

두 대상자 모두 IIC형 보청기가 눈에 보이지 않는다는 점에서 매우 만족한다고 보고하였다. 대상자 1 의 경우 전화받기의 불편 함을 호소하였으나 보청기 교체 이후 이 부분이 해결되었음에 만족감을 표시하였다. 


\section{DISCUSSIONS}

본 사례는 보청기 착용 시 자신의 목소리의 울림을 호소하여 $\mathrm{RIC}$ 형 보청기를 착용하던 난청인이 전화기 사용의 불편함과 미 용상의 이유로 IIC형 보청기로 교체한 후 폐쇄효과와 아울러 전화기의 사용과 미용상의 핸디캡을 해결한 사례이다. 본 사례 의 결과 두 대상자 모두 기존에 착용하던 RIC형 보청기를 IIC 형 보청기로 교체한 후 실이측정, 기능이득, 단어인지도 평가 그 리고 주관적인 보청기이득평가에서 RIC형 보청기와 새로 착용 한 IIC형 보청기의 차이가 없는 것으로 나타났다. 본 연구에서 폐쇄효과의 측정 시 본인의 목소리가 울리는 정도를 대상자의 주관적인 답변을 토대로 보고한 것은 본 연구의 한계점이기는 하지만, Winkler et al.(2016)의 연구에 따르면 울림에 대한 주 관적인 표현은 저주파수의 객관적인 측정과 큰 차이가 없었다 는 보고를 고려할 때 폐쇄효과의 평가에 무리는 없을 것으로 생각한다.

본 사례에 참여한 두 대상자 모두 IIC형 보청기로 교체한 후 폐쇄효과가 해소되지 않을 것을 우려하였으나 두 명 모두 본인 의 목소리가 울려서 들리는 현상에 대해서 불만을 나타내지 않 았다. 두 대상자들이 착용한 IIC형 보청기는 폐쇄효과를 최소화 하기 위하여 최대한 고막 가까이 삽입하고 보청기 중 골부의 표 면이 외이도와 최대한 밀착될 수 있도록 제작하였다. Lee \& Lee(2013)와 Dillon(2012)은 보청기를 착용하고 폐쇄모음 /이/를 발성했을 때 보청기의 골부 부분이 고막 가까이 위치하고 보청기 의 표면이 외이도의 표면과 밀착될 때 저주파수의 REIG가 감소 한다고 하였다. 그리고 Lee \& Park(2016)은 /이/를 발성했을 때 $\mathrm{CIC}$ 형 보청기에 비해서 고막 쪽으로 더 깊이 삽입되는 IIC형 보청기의 REIG가 저주파수에서 더 낮게 나타났다고 보고하였 다. 본 사례에서 $\mathrm{IIC}$ 형 보청기를 착용했을 때에도 RIC형 보청기 와 마찬가지로 울림을 호소하지 않아서 대상자들의 폐쇄효과가 해결된 것을 증명할 수 있었다. 또한 대부분의 $\mathrm{CIC}$ 형 보청기 또 는 귀걸이형 보청기의 귀꽃이 끝 부분은 주로 외이도의 골부에 해당하는 부분에 닿게 된다. 폐쇄효과는 성대의 울림이 하악을 통해 외이도 내로 전달되어 재생성된 음향에너지가 등으로 인해 외이도 밖으로 배출되지 못할 때 발생하게 된다. 또한 $\mathrm{Gal}-$ ster(2011)는 일반적인 귀걸이형, CIC형 및 IIC형 보청기를 착용 한 후 /이/를 발성하고 실이폐쇄이득(real-ear occluded response, REOR)을 측정했을 때 IIC형 보청기의 REOR이 가장 작게 나타났다고 하였다. 그러므로 IIC형 보청기의 경우 다른 보청기에 비해 외이도의 골부 부분에 닿는 면적이 많지만 외이 도 입구에 닿는 면적이 적기 때문에 폐쇄효과를 효과적으로 줄 일 수 있다.

서론에서도 언급하였듯이, 개방적합보청기와 귓속형 보청기
는 서로가 장단점을 가지고 있다. 개방적합보청기는 착용의 간 편함, 음질, 방향성 등의 개선에 효과적이지만 증폭음과 비증폭 음의 상호작용에 의한 음질의 저하 그리고 방향송화기와 잡음 제어 기능에 나쁜 영향을 줄 수 있다(Winkler et al., 2016)는 단 점을 가지고 있다. 또한 청력역치레벨이 너무 높은 경우는 음향 피드백으로 인해 충분한 이득을 제공하기가 어렵다. 그리고 고 막 가까이 삽입하는 IIC형 보청기 등의 경우는 귓본의 채취, 보 청기의 착용감, 외이도의 직경, 외이도의 굴곡 등에 있어서 문 제점이 나타날 수 있다. 따라서 울림을 호소하는 난청인에게 보 청기를 선택하는 경우 청력손실의 정도, 보청기에 대한 선호도, 외이의 상태 등을 고려하여 보청기의 형태를 선택하여야 한다.

미국의 경우, RIC형 보청기가 2013년에는 전체 보청기 판매 의 50\% 이상을 넘었으며(Strom, 2013), 이 수는 앞으로 더욱더 늘어날 전망이다. RIC형 보청기를 선택하는 가장 큰 이유는 미 용과 착용 시 편안함이었다(Kochkin, 2010; Morla, 2011). 하지 만 본 사례의 두 대상자는 울림현상의 문제로 RIC형 보청기를 착용하였으나 전화기 사용의 불편함 그리고 보청기가 타인에게 드러나는 것에 대한 거부감으로 모두 귓속형 보청기를 선택하 였다. 서양의 경우와 우리나라의 보청기를 바라보는 시각의 차 이라고 볼 수 있지만 아직까지 한국에서의 보청기 인식에 대한 조사가 없어 이에 대한 연구가 필요하다.

본 사례에서 RIC형 보청기를 착용했을 때 전화기의 사용에 있어서 불편함을 느끼거나 보청기가 타인에게 노출되는 것을 염려하는 경우는 IIC형 보청기를 통해 폐쇄효과는 물론 전화기 의 사용 및 미용적인 핸디캡을 효과적으로 개선할 수 있음을 확인하였다. 폐쇄효과는 실이측정 등을 통하여 측정하는 것이 효과적이지만 본 사례에서는 대상자의 주관적인 답변을 통해 결과를 구한 것을 한계점으로 볼 수 있다. 하지만 본 사례는 보 편적으로 RIC형 보청기만 폐쇄효과를 해결할 수 있는 것이 아 니라 IIC형 보청기 또한 이득, 어음인지도, 주관적인 보청기의 이득 등을 만족시킬 수 있었다는 점에서 의의를 찾을 수 있을 것이다. 향후의 연구에서는 청력손실역치레벨, 신체적 및 심리 음향적 요인에 따라 개방적합보청기 또는 귓속형 보청기를 효 과적으로 선택할 수 있는 가이드라인을 제시할 수 있는 연구가 필요할 것으로 보인다.

중심 단어 : 폐쇄효과·RIC형 보청기·IIC형 보청기· 전화기 사용·미용.

\section{REFERENCES}

Carle, R., Laugesen, S., \& Nielsen, C. (2002). Observations on the relations among occlusion effect, compliance, and vent size. Journal of the American Academy of Audiology, 13(1), 25-37.

Dillon, H. (2012). Hearing aids. (2nd ed). Stuttgart, New York: Thieme. Fretz, R. J., Stypulkowski, P. H., \& Woods, R. T, inventor; Gn Resound Cor- 
poration, assignee. Open ear canal hearing aid system. United States patent US 6275596. 2001 August 14.

Galster, J. A. (2011). Benefits of Deep-Canal Hearing aid Fittings. Retrieved from https://starkeypro.com/pdfs/technical-papers/Deep_Canal_Fittings_Technical_Paper.pdf.

Kiessling, J., Brenner, B., Jespersen, C. T., Groth, J., \& Jensen, O. D. (2005). Occlusion effect of earmolds with different venting systems. Journal of the American Academy of Audiology, 16(4), 237-249.

Kim, T., Sim, S., \& Lee, K. (2016). Development of Korean Version of Profile of Hearing Aid Benefit. Audiology and Speech Research, 12(4), 209-220.

Kochkin, S. (2010). MarkeTrak VIII: Consumer satisfaction with hearing aids is slowly increasing. The Hearing Journal, 63(1), 19-32.

Korean Agency for Technology and Standards. (2009). Acoustics-Audiometric Test Methods-Part 3: Speech Audiometry. KSI ISO 8253-3. Seoul: Korean Agency for Technology and Standards.

Kuk, F. \& Keenan, D. (2006). How do vents affect hearing aid performance? Hearing Review, 13(2), 34-42.

Lee, K. \& Park, J. (2016). Proceeding from 2016 19th Korean Academy of Audiology: Comparison of occlusion effect on completely-in-the canal and invisible-in-the canal hearing aid. (pp. 83-84). Seoul.

Lee, S. Y., Lee, K. W., \& Lee, J. (2005). A study of the occlusion effect for completely-in-the-canal hearing aids as a function of the vent length and residual volume. Journal of Audiology and Otology, 9(2), 175-179.

Lee, S. H. \& Lee, K. W. (2013). The acoustic and psychoacoustic changes of occlusion effect as a function of bony part length in CIC hearing aid. Audiology and Speech Research, 9(2), 157-164.

Morla, A. (2011). Four transformative patient demands: Convenience, size, simplicity, and flexibility. The Hearing Review, 18(4), 36-42.

Mueller, H. G. (2006). Open is in. The Hearing Journal, 59(11), 11, 12, 14.

Pirzanski, C. (1998). Diminishing the occlusion effect: Clinician/manufacturer relative factors. Hearing Journal, 51(4), 66-78.

Strom, K. (2013). Hearing aid sales flat in first quarter; Wireless $70 \%$ of market. The Hearing Review, 20(5), 6.

Taylor, B. (2006). Real-world satisfaction and benefit with open-canal fittings. The Hearing Journal, 59(11), 74, 76, 78, 80-82.

Winkler, A., Latzel, M., \& Holube, I. (2016). Open versus closed hearing-aid fittings: A literature review of both fitting approaches. Trends in Hearing, 20, 2331216516631741. 